\title{
Öğrencilerin Sahip Oldukları Zihinsel Modellerin Modelleme Süreci İçerisinde İncelenmesi: Hücre Konusu Örneği
}

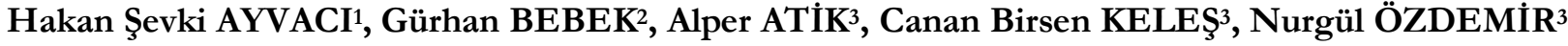 \\ ${ }^{1}$ Dos. Dr. , Karadeniz Teknik Üniversitesi, hsayvaci@gmail.com \\ ${ }^{2}$ Ögr. Gör., Avrasya Üniversitesi, gurban.bebek@gmail.com \\ ${ }^{3}$ Yükesek Lisans Ögrencisi, Karadeniz. Teknik Üniversitesi
}

DOI: http://dx.doi.org/10.14582/DUZGEF.711

\begin{abstract}
ÖZ
Bu çalışma, öğrencilerin hücre konusunda sahip oldukları zihinsel modellerin modelleme süreci içerisinde incelenmesi amaciyla yürütülmüștür. Betimsel nitelikte olan bu çalıșmada özel durum yöntemi tercih edilmiștir. Araştırmanın katılımcılarını Trabzon ili Maçka ilçesinde bulunan bir ortaokulun 6. sınıfinda öğrenim gören 18 öğrenci oluşturmaktadır. Araştırmada veri toplama aracı olarak yarı yapilandırılmış mülakat formu kullanılmış̧ır. Yarı yapılandırılmıș mülakat formundan elde edilen veriler NVivo 9 Programı kullanılarak betimsel analize tabi tutulmuștur. Bu veriler, fen bilimleri eğitimi alanında uzman bir öğretim elemanı tarafından ayrıca tekrar sınıflandırılmıs ve yapılan sınıflandırmalar karşılaştırılarak bağımsız gözlemciler arası uyum NVivo 9 Programı kullanılarak 0.72 (Kappa Güvenirlik Katsayısı) olarak hesaplanmıştır. Grupların yarı yapılandırılmış mülakat sorularına vermiş oldukları yanıtlar doğrultusunda elde edilen veriler ise tablolar ve şekiller olarak sunulmuştur. Araştırmada öğrencilerin psikomotor yeterliklere bağlı olarak tanımlamalar yaptıkları, model konusunda çeşitli yanılgılara sahip oldukları, bilgi ve iletişim teknolojilerini etkin bir şekilde kullandıkları ve sahip oldukları zihinsel modellerin modelleme sürecini etkilediği sonuçlarına ulaşılmışır.
\end{abstract}

Anahtar Kelimeler: Zihinsel model, modelleme süreci, hücre

\section{Investigate of the Students' Mental Models in Modeling Process: The Case of Cell}

\begin{abstract}
The present study aimed to examine students' mental models that they possess within modeling process for cell subject. This study showed characteristics of a descriptive study. Case study method involving 18 6th grade students who attend secondary school in Maçka district in Trabzon was conducted. Data collection tool was semi structured interviews. Descriptive analysis was applied by using Nvivo 9 software. Data obtained from interviews was categorized once again by an expert and Kappa coefficient between independent observers was calculated as 0.72 . Findings were presented as tables and figures. It has been found out that students made statements depending on psychomotor skills, had various misunderstanding on modeling and used information and communication technologies effectively. Besides, it was concluded mental models that students possess affected modeling process.
\end{abstract}

Keywords: Mental model, modeling process, cell

\section{GİRIŞ}

Bilimin toplumlara yön verdiği günümüz dünyasında, bilimin kendisi kadar bilimi üretebilen insanlara olan ihtiyaç da hızla artmaktadır. Toplumlar, ekonomik ve sosyal gelişimlerini sağlayabilmek için her alanda farklı bilgilere gereksinim duymaktadırlar. Toplumların bu gereksinimleri diğer toplumlara olan bağımlılılarını da arttırmaktadır. Dolayısıyla da bir toplumun gelişimini sürdürebilmesi için bilgiyi almak yerine üretmesi gerekmektedir. Bu nedenle de toplumların nitelikli insan yetiştirme hususuna eğilmesi gerekmektedir (Batı, 2014). Nitelikli insan yetiştirme, bireylere bilgiye ulaşabilme yollarını gösterme ve bireylerin sahip oldukları bilgiler ile yeni ürünler ortaya koymasını sağlama fen biliminin amaçları arasındadır (Ayvacı \& Çoruhlu, 2012). 
Fen eğitimi araştıran ve sorgulayan bireyler yetiştirme amacıyla karşımıza çıkan bir disiplin olmasının yanı sıra, öğrencilerde doğa olaylanı ile ilgili kavramların ve kavramlar arası ilişkilerin oluşturulmasını sağlayan bir süreç olarak ifade edilmektedir. Bu süreçte yer alan kavramlar, yapılarına ve varoluş şekillerine göre farkl1lık göstermektedirler (Ünal \& Ergin, 2006). Bazı kavramlar somut ve deneyim yaşanmasına izin verirken, bazıları ise doğrudan gözlenemeyen ve deneyim yaşama imkânı sunmayan soyut ve karmaşık kavramlardır. Fen eğitiminde; soyut, karmaşık ve zor olan kavramlar somutlaştırılarak veya bazı somut olan kavramlar daha anlaşılır hale getirilerek öğretme ve öğrenme sürecinin etkililiğini arttıran çeşitli araçlar bulunmaktadır (Ünal Çoban, 2009). Bu soyut, somut ve karmaşık kavramları daha anlaşıllır hale getiren, öğrencilerin kendi kendilerine öğrenmelerini sağlayan ve öğrenme kaynağı ile doğrudan etkileşimde bulunmalarına olanak tanıyan (Gümüş ve diğerleri, 2008) araçlardan biri de modellerdir.

Modeller ile ilgili literatür incelendiğinde çeşitli tanımlar karşımıza çıkmaktadır. Ünal ve Ergin (2006) model tanımına yönelik olarak soyut, doğrudan gözlenemeyen bazen de somut olduğu halde ölçeklendirilmeye gereksinim duyulan durumlarda kullanılan araçlardır. Harrison (2001), modeller karmaşık bir nesne veya sürecin basitleştirilmiş temsilidir. Modeller nesnelerin oluşumunu, davranışlarını ve sürecin gelişimini anlamamızı ve bunlara ilişkin öngörüde bulunmamızı sağlayan yapılardır. Örnek (2008) model kavramına yönelik olarak modellerin gerçeğin tüm özelliklerini yansıtmadıklarını belirtmiştir. Bu nedenle modeller gerçeğin tam bir kopyası değildirler ve temsil ettikleri hedefe ilave olarak ek açılamalar da içerirler (Gobert ve Buckley, 2000; Harrison, 2001). Yani model temsil ettiği gerçek cisimden büyük, küçük ya da cisim ile tamamen aynı büyüklükte ve yapıda olabilir (Justi \& Gilbert, 2002). Modellerin tanımlarına yönelik olarak literatürden elde edilen veriler sonucunda öğrencilerin model oluşturma ve kullanma etkinliklerine modelleme adı verildiği görülmektedir. Bilimsel bir çalışma olan modelleme ise model oluşturma sürecinde kullanılan işlemlerdir (Justi \& Gilbert, 2002). Fen eğitimi literatürü incelendiğinde modelleme, mevcut kaynaklardan hareketle bilinmeyen bir hedefi açık ve anlaşılır hale getirmek için yapılan işlemler bütünü olarak ifade edilirken, modelleme olarak adlandırılan bu süreç sonucunda ortaya çıkan ürün ise model olarak nitelendirilmektedir (Koçak, 2006). Nitelendirilen bu modeller 2000'li ylllarda Harrison ve Treagust tarafindan sistematik ve düzenli olarak ayrıntılı bir şekilde sınıflandırılmışır. Bunlar ölçek modelleri, pedagojik analojik modeller, simgesel veya sembolik modeller, matematiksel modeller, teorik modeller, harita- diyagram-tablolar, kavram-süreç modelleri, simülasyonlar, senteze dayalı modeller ve zihinsel modellerdir.

Zihinsel modeller, bilişsel faaliyetler sonucunda (Coll \& Treagust, 2003) öğrencilerin modelleme etkinliklerinde düşünme biçimlerini göstermek ve buna bağlı olarak davranışlarını sergilemek adına zihinlerinde oluşturdukları bireye özgü ve içsel temsillerdir. Bu temsiller öğrencilerin sahip oldukları alan bilgisine bağlı olarak şekillendiği için bu yapılar içerisinde eksikliklerinin olduğu karşımıza çıkmaktadır. Kurnaz ve Değermenci (2012) tarafından öğrencilerin Güneş, Dünya ve Ay ile ilgili zihinsel modellerini tespit etmek için yürütülen çalışmada alan bilgisi konusunda sorunlar yaşayan öğrencilerin bu durumu zihinsel modellerine de yansıttıkları ortaya konularak, oluşturulan zihinsel modellerde alan bilgisi eksikliği de gözler önüne serilmiştir. Bu duruma paralel bir şekilde Méheut (2004), öğrencilerin maddenin tanecikli yapısına ilişkin zihinsel modellerini belirlemek amacıyla yürüttüğü çalısmada, alan bilgisinin zihinsel modelleri tanımlama sürecinde oldukça önemli olduğunu ifade etmiştir. Buna bağlı olarak da alan bilgisi ile ilgili eksikliklerin zihinsel modellere yansıdıkları ve bir öğrencinin kavram yanılgısının tespit edilmesinde zihinsel modellerin kullanılabileceği ifade edilmiştir.

Literatür incelendiğinde öğrencilerin modelleme süreçlerindeki zihinsel modellerini tespit etmeye yönelik çeşitli çalışmalar karşımıza çıkmaktadır. Atom (Altuntaş Aydın, 2011; Minaslı, 2009; Nakiboğlu, Karakoç \& Benlikaya, 2002; Yıldız 2006), kimyasal denge (Bilgin ve Geban, 2001), kalıtım (Esendemir, 2014; Kaptan \& Arslan, 2002), astronomi (İyibil \& Arslan, 2010; Küçüközer, 2008; Ogan-Bekiroğlu, 2007), hareket ve mekanik (Başkan, 2011; Hestenes, 2006; Woolridge, 2000), basınç (Ünal, 2005), 1şık (Ünal Çoban, 2009) ve 1S1 (Arslan, 2013) bu konular arasındadır. Bunun yanı sıra Aydın (2011) öğrencilerin hücre konusundaki 
zihinsel modellerini inceleyen çalışmasında, modelleme sürecine bağlı olmadan bir değerlendirme yapmıştır. Ancak öğrencilerin sahip olmuş olduğu zihinsel modeller modelleme sürecinden bağımsız olarak değerlendirilemez. Bu bağlamda da literatürde hücre konusu ile ilgili olarak eksiklik karşımıza çıkmaktadır. Bu çalışma da, literatürde yer alan bu eksikliği gidermek ve öğrencilerin hücre konusundaki zihinsel modellerini modelleme sürecinde tespit etmek amaciyla yürütülmüştür.

Araştırmanın problemi "Öğrencilerin hücre konusunda sahip oldukları zihinsel modeller nelerdir?" olarak belirlenmiştir. Bu ana problem cümlesine bağlı olarak araştırmanın diğer alt problemleri ise şu şekilde belirlenmiştir:

6.sınıf öğrencilerinin modeller ve özellikleri konusunda sahip olduklanı görüşler nelerdir?

$>$ Model oluşturma konusunda öğrenciler tarafindan hangi araştırma kaynakları kullanılmaktadır?

> Öğrencilerin modelleme sürecinde araştırma kaynaklarını tercih etme nedenleri nelerdir?

> Öğrenciler modelleme etkinliklerinde ne tür malzemeler kullanmayı düşünmektedirler?

> Öğrenciler modelleme etkinliklerinde ne tür sorunlar ile karşılaşmaktadırlar?

> Öğrenciler modelleme etkinliklerinde karşılaştkları sorunlara ne tür çözümler üretmektedir?

> Öğrencilerin modelleme etkinliklerinde zihinsel modelleri ile oluşturdukları modeller arasında fark var midir?

\section{YÖNTEM}

Araştırmanın yöntem başlığı altında araştırmanın modeli, veri toplama aracı, veri toplama süreci ve analizi ve araştırmada geçerlik ve güvenirlik konularına değinilecektir.

\subsection{Araştırmanın Modeli}

Betimsel nitelikte olan bu çalışma, özel durum yöntemi kullanılarak yürütülmüştür. Bu yöntem, özel bir konu veya durum üzerinde derinlemesine inceleme yapma imkânı vermektedir (Creswell, 2003). Araştırma kapsamında da öğrencilerin hücre konusu ile ilgili zihinsel modellerinin derinlemesine incelenmesi amaçlandığ1 için bu yöntem tercih edilmiştir. Araştırmanın katılımcılarını Trabzon ili, Maçka ilçesinde bulunan bir ortaokulun 6. sınıfinda öğrenim gören 18 öğrenci oluşturmaktadır. Bu 18 öğrenci ise öğretmen tarafindan (her grupta üç ögrrenci olmak üzere) rastgele olarak altı farklı gruba ayrılmıştır. Araştırmada etik kuralları gereği gruplar G1, G2, ... ve G6 şeklinde ifade edilmiştir.

\subsection{Veri Toplama Arac1}

Öğrencilerin hücre konusundaki zihinsel modellerini ortaya çıkarmak amacıyla yürütülen araştırmada veri toplama aracı olarak yarı yapılandırılmış mülakat formu kullanılmışıtır. Yarı yapılandırılmış mülakat formu, sahip olduğu belli düzeydeki standartlığı, esnekliği ve belirli bir konuda derinlemesine bilgi edinmeye yardımcı olması (Yıldırım \& Şimşek, 2003) nedeniyle tercih edilmiştir. Yarı yapılandırılmış mülakat formu hazırlanmadan önce literatür taraması yapılarak araştırma alanı ile ilgili genel bilgiler edinilmiştir. Elde edilen bilgiler fen eğitimi alanında uzmanın görüşüne başvurularak yarı yapılandırılmış mülakat formu revize edilmiştir.

\subsection{Veri Toplama Süreci ve Analizi}

Oluşturulan yarı yapılandırılmış form, araştırmacılar tarafından modelleme etkinlikleri esnasında toplam dört ders saatinde uygulanmıştır. Bu süreçte hazırlanmış olan yarı yapılandırllmış mülakat soruları öğrencilere sorulmuş ve cevaplar ses kayıt cihazı ile kayıt altına alınmıştır. Elde edilen ses kayıtları düz yazı haline getirildikten sonra, NVivo 9 Programı kullanılarak betimsel analize tabi tutulmuştur. Betimsel analiz, bir metnin bazı sözcüklerinin daha küçük içerik kategorileri ile özetlendiği sistematik bir tekniktir. Araştırmacılar metin içerisinde geçen anahtar kelimelere bağlı olarak kavramların varlı̆̆ını, anlamını ve ilişkilerini betimlemek amacıyla bu yönteme başvururlar (Büyüköztürk ve diğerleri, 2011). Öğrenciler ile yürütülen yarı yapılandırılmış mülakatlar sonucunda elde edilen veriler, fen bilimleri eğitimi alanında uzman bir öğretim elemanı tarafindan 
ayrıca tekrar sınıflandırılmış ve yapılan sınıflandırmalar karşılaştırılarak bağımsız gözlemciler arası uyum (Çepni, 2010) ile çalışmanın güvenirliği sağlanmaya çalışılmıştır.

\subsection{Araştırmada Geçerlik ve Güvenirlik Konuları}

Çalışmanın geçerlik faktörü için iç ve dış geçerlik unsurları göz önünde bulundurulmuştur. Çalışmanın iç geçerliği için araştırmacılar tarafından üye kontrol işlemi gerçekleştirilmiştir. Araştırmada iç geçerliğin arttırılmasında kullanılan yöntemlerden biri olan üye kontrolleri, elde edilen sonuç ve çıkarımların makul veya mantıklı olup olmadığını veri kaynakları ile birlikte tekrardan kontrol etme işlemidir (Cohen, Manion ve Morrison, 2000). Bu bağlamda da çalışmanın katılımcılarından elde edilen veriler araştırmacılar tarafindan kontrol edilerek iç geçerlilik arttırılmıştır. Araştırmanın dış geçerliği için de katılımcı grubundan elde edilen veriler zengin ve ayrıntılı bir biçimde okuyucuya sunulmuştur. Bu sunum işlemleri esnasında ise özgün ve kalıcı kategorilerin oluşturulması hususlarına özen gösterilmiştir.

Araştırmada güvenirlik için Nvivo 9 Programı kullanılmıştır. Bağımsız iki gözlemcinin yaptığı sınıflandırmadan elde edilen verilerin kodlamalarının tutarlılık oranları NVivo 9 Programı kullanılarak 0.72 (Kappa Güvenirlik Katsayısı) olarak hesaplanmıştır. Kappa katsayısı 0.40 ile 0.75 arasında ise makul bir uyuşma, 0.75 ve daha büyük ise mükemmel bir uyuşma olduğu anlamına gelmektedir (Şencan, 2005). Bu oran, bağımsız gözlemciler tarafindan yapılan puanlamalar arasında tutarlılık olduğunu, testin kategorilere göre analizinin güvenilir olduğunu göstermektedir. Farklı olan kodlamalar için ise bağımsız gözlemciler fikir birliğine varmışlardır.

\section{BULGULAR}

Öğrencilerin hücre konusunda sahip olduklan zihinsel modelleri ortaya çıkarmak amacıyla yürütülen bu araştırmada yarı yapılandırılmıs mülakatlardan elde edilen bulgular aşağıdaki gibidir. Araştırmanın alt problemleri göz önünde bulundurularak araştırmacılar tarafindan öğrencilere yöneltilen "Model yapmaya karar verdiğimizde ilk olarak ne düs̆̈̈ndünüz?" sorusuna yönelik olarak gruplardan alınan cevaplar Tablo 1'de sunulmuştur.

Tablo 1. Katılımcı Grupların Model ile İlgili Düşünceleri

\begin{tabular}{lcccccc}
\hline GÖRÜŞLER & G1 & G2 & G3 & G4 & G5 & G6 \\
\hline Modelin Fiziksel Özellikleri & X & & X & X & X & \\
\hline Modelin İçerik Özellikleri & & X & & & & X \\
\hline Modellerin Dikkat Çekici Olmas1 & & & X & & & \\
\hline Modellerde Kullanilacak Malzemeler & X & X & & & & X \\
\hline Bitki Hücresi Modeli & & & X & X & & \\
\hline Hayvan Hücresi Modeli & X & X & & & X & X \\
\hline
\end{tabular}

Tablo 1 incelendiğinde, gruplann model ile ilgili düşüncelerinin modelin fiziksel özellikleri (G1, G3, G4, G5), modelin içerik özellikleri (G2, G6), modellerin dikkat çekici olması (G3), modellerde kullanılacak malzemeler (G1, G2, G6), bitki hücresi modeli (G3, G4, G5) ve hayvan hücresi modeli (G1, G2, G6) konularında şekillendiği karşımıza çıkmaktadır. "Model yapmaya verdiğimizde ilk olarak ne düşündünüz?” sorusuna yönelik

G1 kodlu grup "Hangi malžremeleri kullanabileceğimizi düşündük. Görüntüsü daha güzel olduğu için hayvan bücresi modelini tercih ettik ve hayvan bücresi modelinde yer alan yapılar nasıl gösterebiliriz, sorusu üzerinde arkadaşlar ile fikir alısverişi yaptık",

G2 kodlu grup "Hangi malžemeleri kullanabileceğimiz̨i düş̈̈ndük. Bitki bücresinin yapılarm göstermek daha zor olduğu için hayvan bücresinin modelini yapmaya karar verdik",

G3 kodlu grup "Öğretmenimiz̧n beğenebileceği bir model yapmayn düşündük. Hayvan bücresi biẓe biraz. karmaşık geldiği için bitki bücresinin modelini yapmaya karar verdik",

G4 kodlu grup "Yapılması kolay olacak olan bücreyi düşündük ve bitki bücresinin modelini yapmaya karar verdik",

G5 kodlu grup "Hayvan bücresin şekli daha ilginc geldiği için hayvan bücresi modelini yapmayn tercih ettike" ve

G6 kodlu grup ise "Hangi malı̧emeleri kullanabileceğimizi düsündük. Hayvan bü̈resinin içerisindeki yapılar daha kolay gösterebileceğimiži düşündük ve hayvan bücresinin modelini yapmayn tercih ettik" şeklinde görüş bildirmiştir. 
Araştırmanın alt problemleri göz önünde bulundurularak araştırmacılar tarafindan öğrencilere yöneltilen “Modellerin sahip olması gereken özellikler nelerdir??' sorusuna yönelik olarak gruplardan alınan cevaplar Tablo 2'de sunulmuștur.

Tablo 2. Katılımc1 Gruplara Göre Modellerin Sahip Olması Gereken Özellikler

\begin{tabular}{lcccccc}
\hline GÖRÜŞLER & G1 & G2 & G3 & G4 & G5 & G6 \\
\hline Görüntü Güzelliği & $\mathrm{X}$ & & $\mathrm{X}$ & $\mathrm{X}$ & & $\mathrm{X}$ \\
Dikkat Çekicilik & & & & $\mathrm{X}$ & & \\
Gerçeği Yansitma & $\mathrm{X}$ & $\mathrm{X}$ & & $\mathrm{X}$ & $\mathrm{X}$ & \\
Öğretmen Tarafindan Beğenilme & & & $\mathrm{X}$ & & & \\
Arkadaş Tarafindan Beğenilme & & $\mathrm{X}$ & $\mathrm{X}$ & & $\mathrm{X}$ & \\
\hline
\end{tabular}

Tablo 2 incelendiğinde grupların, modellerin sahip olması gereken özellikler ile ilgili olarak görüntü güzelliği (G1, G3, G4, G6), dikkat çekicilik (G4), gerçeği yansıtma (G1, G2, G4, G5), öğretmen tarafindan beğenilme (G3) ve arkadaş tarafından beğenilme (G2, G3, G5) konularında görüş bildirdikleri karşımıza çıkmaktadır. "Modellerin sahip olması gereken özellikler nelerdir?” sorusuna yönelik

G1 kodlu grup "Modelin görüntüsünün güzel olması ve en önemlisi model üzerindeki bilgilerin gerçekteki olan ile birebir doğru olması gerekir",

G2 kodlu grup "Modeller oluşturulan yapıya ait öz̧ellikleri içermeli ve arkadaşlar tarafinda övülmelidir",

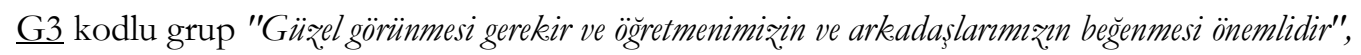

G4 kodlu grup "Modelin güzel görünmesi ve model üzerindeki yapılarm doğru gösterilmis olması önemlidir. Ayrıca model dik.kat cekici de olmaluder",

G5 kodlu grup "Model üzerindeki bilgilerin doğruyu yansitması önemlidir. Ayrica sinıf içerisinde herkes tarafindan takdir kazanmalder" ve

G6 kodlu grup ise "Modellerin görüntüleri güzel olmahdrr" şeklinde görüş beyan etmişlerdir.

Araştırmanın alt problemleri göz önünde bulundurularak araştırmacılar tarafından öğrencilere yöneltilen "Araştırma sürecinde ne tür araștırma kaynaklarm kullandmı̨? Bu araștırma kaynaklarm tercih etme nedenleriniz. nelerdir?’' sorusuna yönelik olarak gruplardan alınan cevaplar Tablo 3'te sunulmuştur.

Tablo 3. Katılımcı Grupların Tercih Ettiği Araştırma Kaynakları ve Nedenleri

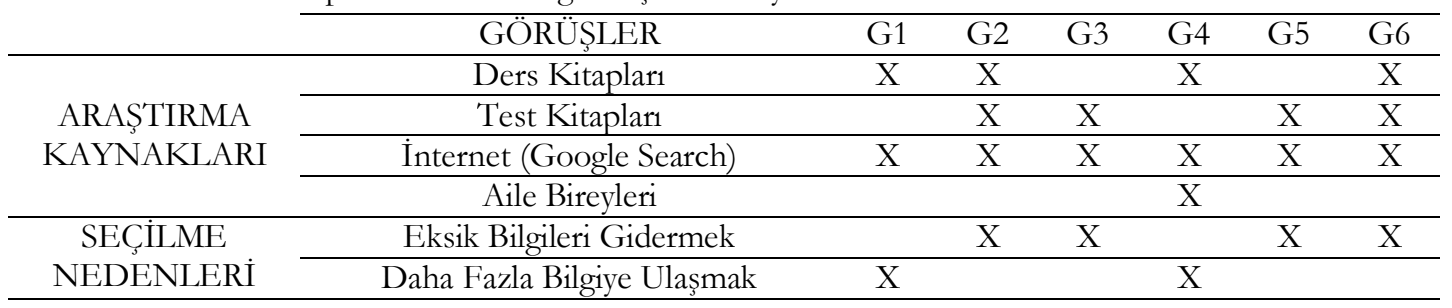

Tablo 3 incelendiğinde grupların, modelleme etkinlikleri için ders kitaplarından (G1, G2, G4, G6), test kitaplarından (G2, G3, G5), internetten (G1, G2, G3, G4, G5, G6) ve aile bireylerinden (G4) araştırma yaptıkları karşımıza çıkmaktadır. Bu araştırma kaynaklarının seçilmesinde ise eksikleri bilgileri gidermek (G2, G3, G5, G6) ve daha fazla bilgiye ulaşmak amacının güdüldüğü gözler önüne serilmektedir. "Araştırma sürecinde ne tür araştırma kaynaklarını kullandınız? Bu araştırma kaynaklarını tercih etme nedenleriniz nelerdir?” sorusuna yönelik

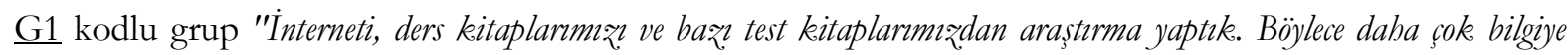
ulaşabileceğimiri düsü̈ndük",

G2 kodlu grup "Eksik bilgilerimizi gidermek için ders kitabından ve test kitaplarndan ve internetten faydalandık",

G3 kodlu grup "Daba iyi bir model yapabilmek için eksik bilgilerimizi test kitaplarndan ve internetten yararlanarak gidermeye çalışıı.”,

G4 kodlu grup "Internetten ve ăgabey ya da ablamızdan yardım aldık. Böylece daba farkh bilgilere ulaștık",

G5 kodlu grup "Bilgilerimizin eksik olduğunu düşündügü̈mü̃ için test kitabı ve bilgisayardan yardım aldık" ve

G6 kodlu grup ise "Bilmediğimiz kavramlar araștırmak için bilgisayar ve kitaplardan yararlandık" şeklinde görüşlerini ifade etmişlerdir. 
Araştırmanın alt problemleri göz önünde bulundurularak araştırmacılar tarafindan öğrencilere yöneltilen "Araştırma sürecinde ne tür malzemeler kullanmayı planlyorsunų?" sorusuna yönelik olarak gruplardan alınan cevaplar Tablo 4'te sunulmuştur.

Tablo 4. Katılımcı Grupların Modelleme Etkinliklerinde Kullanmayı Planladığı Malzemeler

\begin{tabular}{lcccccc}
\hline GÖRÜŞLER & G1 & G2 & G3 & G4 & G5 & G6 \\
\hline Jöle & $\mathrm{X}$ & & & & & \\
Bant & $\mathrm{X}$ & & & & & \\
Boncuk & $\mathrm{X}$ & & $\mathrm{X}$ & & & $\mathrm{X}$ \\
Bakır Tel & $\mathrm{X}$ & & & & & \\
Karton & & $\mathrm{X}$ & & & & \\
Oyun Hamuru & & $\mathrm{X}$ & $\mathrm{X}$ & $\mathrm{X}$ & $\mathrm{X}$ & \\
İp & & $\mathrm{X}$ & $\mathrm{X}$ & & \\
Düğme & & $\mathrm{X}$ & & & \\
Çubuk & & & $\mathrm{X}$ & & \\
Kabak & & & & & $\mathrm{X}$ \\
Peçete & & & & & & $\mathrm{X}$ \\
\hline
\end{tabular}

Tablo 4 incelendiğinde grupların, modelleme etkinliklerinde jöleyi (G1), band1 (G1), boncuğu (G1, G3, G6), bakır teli (G1), kartonu (G2), oyun hamurunu (G2, G3, G4, G5), ipi (G3, G4), düğmeyi (G3), çubuğu (G4), kabağı (G6) ve peçeteyi (G6) kullanmayı planladıkları karşımıza çıkmaktadır. Araştırma sürecinde ne tür malzemeler kullanmayı planlıyorsunuz?” sorusuna yönelik

G1 kodlu grup "Yapılarn birbirinden ayurt edilebilmeleri için jöle, bant, boncuk ve bakur tel kullanmak istiyoruz",

G2 kodlu grup "Dikekat çekmesi için farkh renklerde oyun hamuru ve karton kullanmayı planliyoruz","

G3 kodlu grup "Oyun hamuru, boncuk, dï̈me ve ip kullanacağgz",

G4 kodlu grup "Oyun hamuru, ip ve çubuk kullanmayn planlyyoruæ: Organellerin görevleri farkh olduğu için farkeh renklerde fark.h malzemeler kullanacă̆ız",

G5 kodlu grup "Canlı renkler kullanmak istedik bu yüzden de oyun hamurunu tercih edeceğiz". ve

G6 kodlu grup ise "Kabak, boncuk ve peçete kullanacă̆g: Malzemelerin farkh olması gerekiyor" şeklinde görüş bildirmiştir.

Araştırmanın alt problemleri göz önünde bulundurularak araştırmacılar tarafından öğrencilere yöneltilen “Araştırma sürecinde ne tür sorunlar ile karşılaştını ve bu sorunlara ne gibi çözüm önerileri getirdiniz??” sorusuna yönelik olarak gruplardan alınan cevaplar Tablo 5’te sunulmuştur.

Tablo 5. Katılımcı Grupların Modelleme Etkinliklerinde Karşılaştığ1 Sorunlar ve Çözüm Önerileri

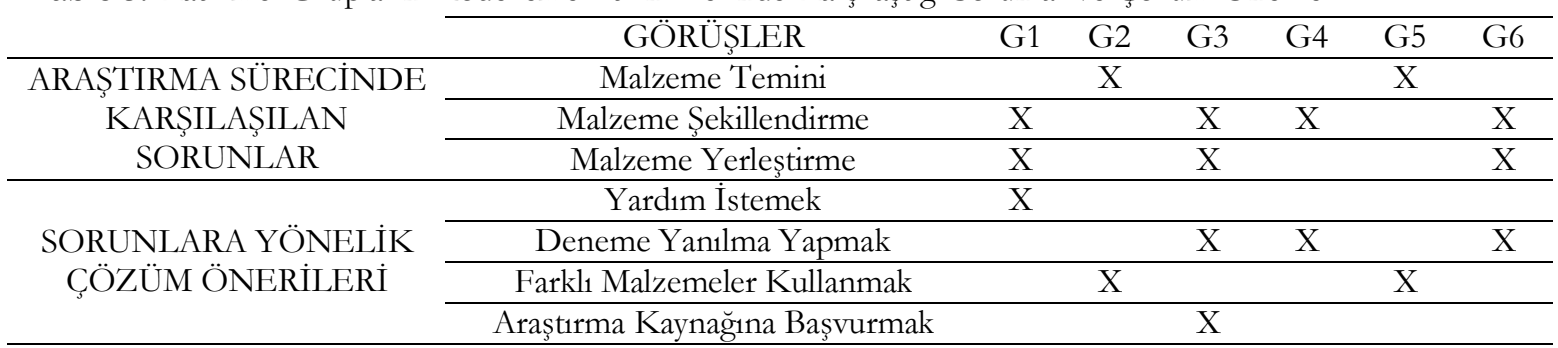

Tablo 5 incelendiğinde grupların, modelleme etkinlilerinde malzeme temini (G2, G5), malzeme şekillendirme (G1, G3, G4, G6) ve malzeme yerleştirme (G1, G3, G6) konularında sorun yaşadıkları görülmektedir. "Araştırma sürecinde ne tür sorunlar ile karşılaştınız?” sorusuna yönelik olarak

G1 kodlu grup "Bakur teli keserken zorlandık. Bir de çekirdeğin içine kahtım maddesini nasıl yerleştireceğimiz. konusunda çok düşündük", G2 kodlu grup "Malz̧emeleri bulmakta zorlandlk", G3 kodlu grup "Organellere şekil verirken ve malzemeleri yerlestirirken zorlandık", G4 kodlu grup "Organelleri sekillendirirken zorlandık", G5 kodlu grup "Malžeme bulmakta zorlandık" ve G6 kodlu grup ise "Kabağa şekil verirken zorlandı. Peçeteleri kabağm içerisine yerleştirirken ıslanması da biz̨i zorladı" şeklinde görüş bildirmişlerdir.

“Araştırma sürecinde karşılaştı̆ı̆ıı sorunlara ne tür çözüm önerileri getirdiniz?” sorusuna yönelik olarak

G1 kodlu grup "Teli kesmeye şalștık ancak yapamaynca yardıma basvurduk", G2 kodlu grup "Elimizde olan malzemeleri kullanmak zorunda kaldık ve sonuc alamadı bu yüzden de o malzemelerden farkh seyler yapmaya çalıstık", G3 kodlu grup "Biraz, denedikten sonra internetten bakarak. malzemeleri yerlestirebildik", G4 kodlu grup "Bir kaç kere 
deneme yaptık", G5 kodlu grup "Farkh malzemeler kullanarak sorunun üstesinden gelebileceğimiz düsünerek farkh malzemeler almaya çalıs̆tık" ve G6 kodlu grup ise "Peçeteleri ilk denemelerimizde yerleștiremeyince en son koymaya karar verdik" şeklinde görüşlerini ifade etmişlerdir.

Araştırmanın alt problemleri göz önünde bulundurularak "Öğrencilerin modelleme etkinliklerinde zihinsel modelleri ile oluşturdukları modeller arasında fark var mıdır?” sorusuna yönelik her grup tek tek ele alınmıştır. Grupların tüm sorulara veriş oldukları yanıtlar göz önüne alınarak oluşturmayı planladıkları modele ait öngörüleri ve oluşturdukları modeller bir arada ifade edilmiştir.

G1 kodlu grubunun hücre konusu ile ilgili zihinsel modelleri ve buna bağlı olarak meydana getirmiş oldukları model şu şekildedir:

\begin{tabular}{|c|c|}
\hline $\begin{array}{ll} & \text { GRUBUN ÖNGÖRÜSÜ ve } \\
& \text { MODELLEME SÜRECİ } \\
\text { - } & \text { Hayvan hücresi } \\
\text { - } & \text { Fiziksel özelliklere dikkat çekme } \\
\text { - } & \text { Modelin doğruluğu } \\
\text { - } & \text { Modeldeki malzemelerin ayırt } \\
& \text { ediciliğine dikkat çekme } \\
\text { - } & \text { Kitap ve internete başvurma } \\
\text { - Jöle, bant, boncuk, bakır tel } & \text { kullanma } \\
\text { - } & \text { Aileden yardım alma } \\
\text { - } & \text { Malzemeleri yerleştirmede ve şekil } \\
& \text { vermede zorlanma }\end{array}$ & $\begin{array}{l}\text { Hayvan hücresi modeli. Pet şişe hücre } \\
\text { zarını, jöle sitoplâzmayl, bilye çekirdeği, } \\
\text { diğer cisimler hücredeki farklı organelleri } \\
\text { temsil etmektedir. }\end{array}$ \\
\hline
\end{tabular}

Şekil 1. G1 Kodlu Grubun Öngörüsü ve Ortaya Çıkardığı Model

G1 kodlu grup araştırma kapsamında hayvan hücresi yapacağını ifade etmektedir. Sonuçta açığa çıkan modele bakıldığında hücrenin şeklinin hayvan hücresine benzediği görülmektedir. Grup, modelde verilmek istenilen bilgilerin doğruluğunun önemine dikkat çekmektedir. Bu bağlamda da, modelde kullanılan jöle, sitoplâzmanın akışkanlığını yansıttığı için zihinsel modellerine uygun bir sonuç elde etmiş oldular. Fakat grubun zihinsel modellerinde malzemelerin ayırt ediciliğine dikkat çekmelerine rağmen, sonuçta ortaya çıkardıkları modelde hücrenin temel yapıları dışında diğer organellerin ayırt edilemediği görülmektedir. G2 kodlu grubunun hücre konusu ile ilgili zihinsel modelleri ve buna bağlı olarak meydana getirmiş oldukları model şu şekildedir:

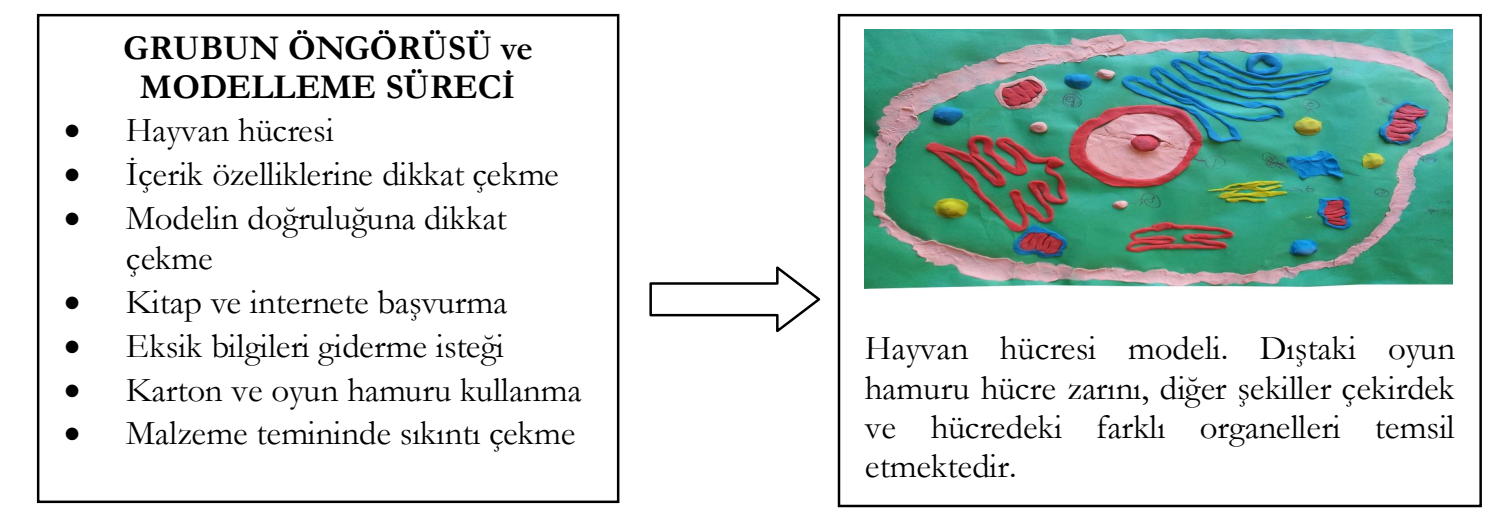

Şekil 2. G2 Kodlu Grubun Öngörüsü ve Ortaya Çıkardığı Model

G2 kodlu grup araştırma kapsamında hayvan hücresi yapacağını ifade etmektedir. Sonuçta açığa çıkan modele bakıldığında hücrenin şeklinin hayvan hücresine benzediği görülmektedir. Grup, zihinsel modelinde, modeldeki bilgilerin doğruluğuna dikkat çekmektedir. Fakat malzeme temini noktasında sıkıntı yaşadıklarından bu amaçlannı tam olarak gerçekleştiremedikleri görülmektedir. Grup, zihinsel modellerinde malzemelerin dikkat çekici olması gerektiğini ifade etmektedir. Sonuçta ortaya çıkan modele bakıldığında kullanılan renklerin farklı ve canlı olması, bu düşüncelerini gerçekleştirdiklerini göstermektedir.

G3 kodlu grubunun hücre konusu ile ilgili zihinsel modelleri ve buna bağlı olarak meydana getirmiş oldukları model şu şekildedir: 
GRUBUN ÖNGÖRÜSÜ ve MODELLEME SÜRECİ

- $\quad$ Bitki hücresi

- Fiziksel özelliklere dikkat çekme

- Modelin güzelliğine dikkat çekme

- İnternete bașvurma

- $\quad$ Eksik bilgileri giderme isteği

- Boncuk, oyun hamuru, ip, düğme kullanma

- Deneme-yanilma yaparak sonuca ulaşma

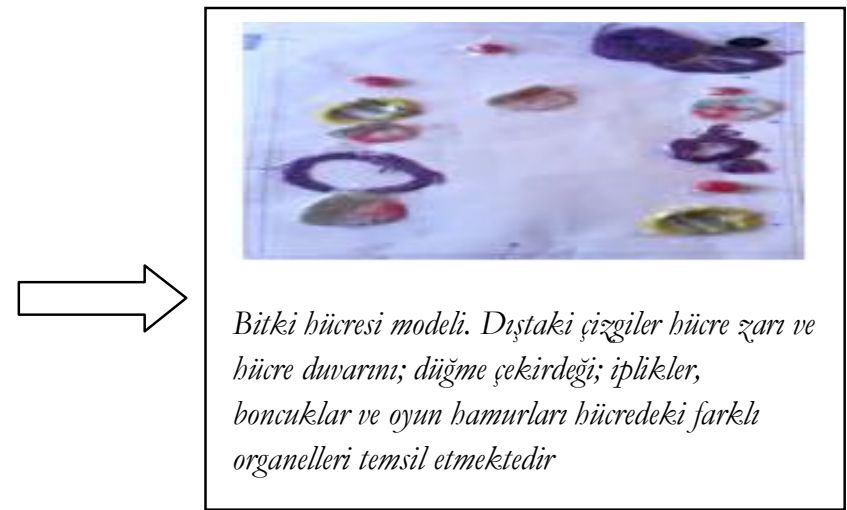

Şekil 3. G3 Kodlu Grubun Öngörüsü ve Ortaya Çıkardığı Model

G3 kodlu grup araştırma kapsamında bitki hücresi yapacağını ifade etmektedir. Sonuçta açığa çıkan modele bakıldığında hücrenin şeklinin bitki hücresine benzediği görülmektedir. Grup, zihinsel modelinde görüntü güzelliğinin önemini ve modelin dikkat çekici olması gerektiğini belirtmişlerdir. Ortaya çıkan modele bakıldığında farklı malzemelerin, farklı şekillerde kullanılmasının bu amaçlanına hizmet ettiklerini göstermektedir. G4 kodlu grubunun hücre konusu ile ilgili zihinsel modelleri ve buna bağlı olarak meydana getirmiş oldukları model şu şekildedir:

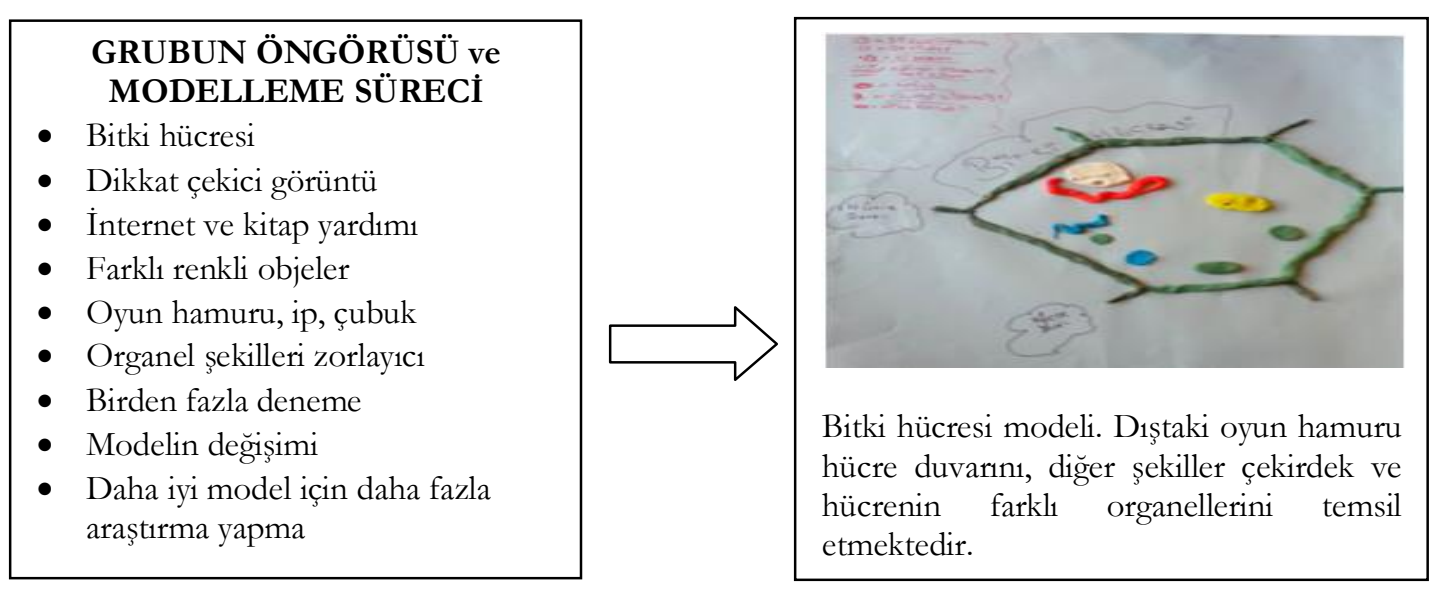

Şekil 4. G4 Kodlu Grubun Öngörüsü ve Ortaya Çıkardığı Model

G4 kodlu grup araştırma kapsamında bitki hücresi yapacağını ifade etmektedir. Farklı renklerde oyun hamurlarını kullanacaklarını ifade etmişler ve bu doğrultuda oluşturdukları modelde bu yapılara rastlanmaktadır. oyun hamuru kullanmışlar. Fakat kullanmayı planladıkları ip çubuk gibi objelere modelde rastlanmamaktadır. Grup organellerin şekillerinde zorlandıklarını ifade etmektedir. Ancak modelde yer alan organellerin şekilleri incelendiğinde gerçeğe benzedikleri göze çarpmaktadır. Son olarak ise modelin renkleri ile ilgi çekici olması gerektiği ifade edilmekte ve bu bağlamda da modeldeki renkler de parlak ve ilgi çekici olduğu görülmektedir.

G5 kodlu grubunun hücre konusu ile ilgili zihinsel modelleri ve buna bağlı olarak meydana getirmiş oldukları model şu şekildedir: 


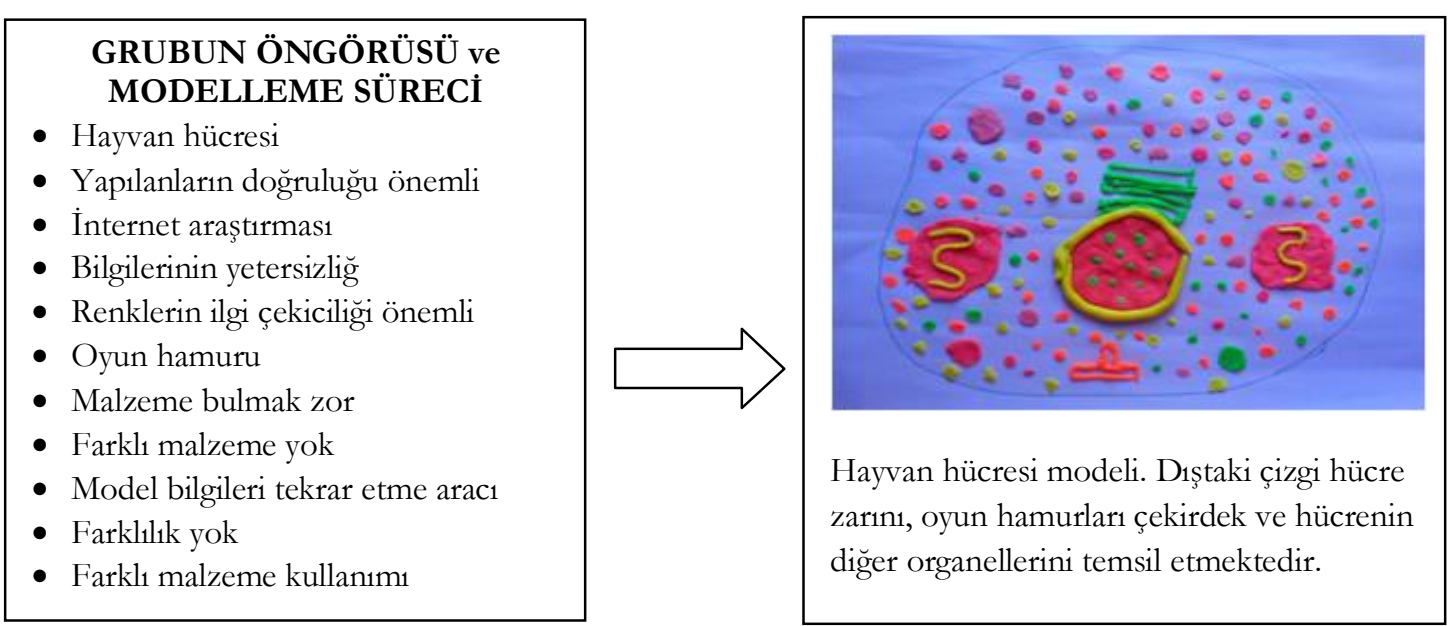

Şekil 5. G5 Kodlu Grubun Öngörüsü ve Ortaya Çıkardığı Model

G5 kodlu grup araşturma kapsamında hayvan hücresi yapacağını ifade etmekte ve meydana getirdikleri model incelendiğinde bu modelin hayvan hücresine ait olması dikkat çekmektedir. İlginç bir model olması gerekliliği ve yapıların doğruluğuna dikkat çekilmekte ve bu nedenle de oyun hamurları gerçeğe benzer şekilde hücre içerisinde yer almaktadır. Farklı renklerde oyun hamurlarını kullanacaklarını ifade etmişler ve bu doğrultuda oluşturdukları modelde bu yapılara rastlanmaktadır. Grup, farklı malzeme seçimi konusunda sorunlar olduğunu düşünmekte ve bu görüşünde pekte yanılmamaktadır. Modellerinde sadece oyun hamurlarına bağlı olarak ürün meydana getirilmektedir. Bu bağlamda da malzeme teminin konusunda sorunlar olması kaçınılmaz bir gerçek olmaktadır. Ayrıca birçok yapıyı oyun hamurları ile meydana getirirken hücre zarını sadece çizimle yapmış olmaları da ayırıca incelenmesi gereken bir konu olarak karşımıza çıkmaktadır. G6 kodlu grubunun hücre konusu ile ilgili zihinsel modelleri ve buna bağlı olarak meydana getirmiş oldukları model şu şekildedir:

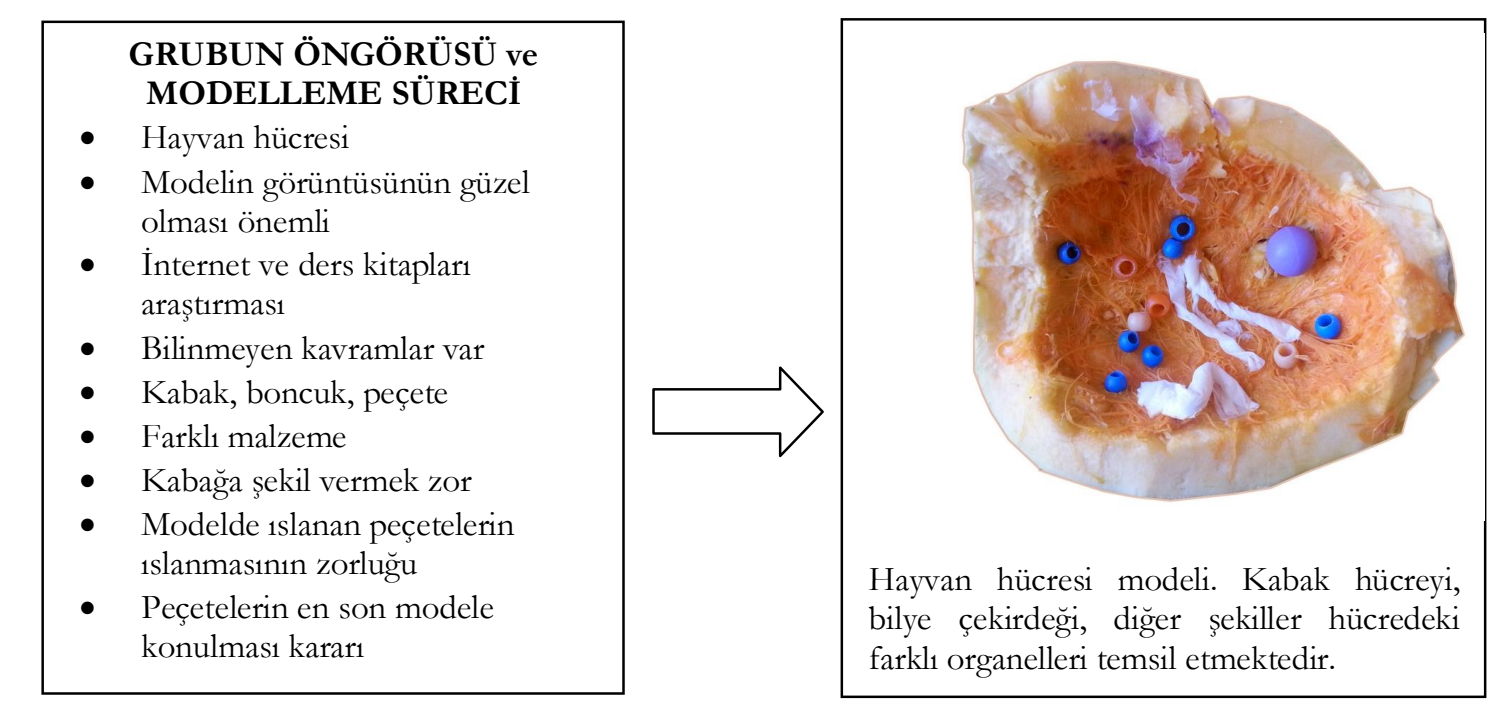

Şekil 6. G6 Kodlu Grubun Öngörüsü ve Ortaya Çıkardığı Model

G6 kodlu grup araştırma kapsamında hayvan hücresi yapacağını ifade etmektedir. Modelin şekli hayvan hücresine benzemektedir. Grup tarafından ifade edildiği üzere modelde kabak, boncuk ve peçete kullanılmaktadır. Kabak kullanmanın zorluğu ve peçetelerin ıslanması hususlanın dikkat çekilmekte bu durum modelde de karşımıza çıkmaktadır. Bu sebeple en son konulmuş olan ve ilk konulan peçetelerin kalıntıları modelde görülmektedir. G6 kodlu grup modelin ilginç olmasını istemektedir. Ortaya çıkan model farklı ve ilgi çekici görünmektedir.

\section{TARTIŞMA}

Araştırma kapsamında model ve özellikleri ile ilgili olarak katılımcı gruplardan alınan görüşlerde özellikle hayvan hücresi tanımımın vurgulandığı görülmektedir. Neden hayvan hücresi? sorusuna ise bu yapının kolay 
bir şekilde ortaya konulabileceği ve bitki hücresi modeline göre daha dikkat çekici olması olarak ifade etmişlerdir. Hayvan hücresi modelinin daha kolay yapılabilir olmasına yönelik olarak öğrenciler sahip oldukları psikomotor yeterliklerin bu modeli seçmelerinde etkili olduğu düşünülmektedir. Psikomotor yeterlilikler, bilim yaparken gereken psikomotor becerileri içermektedir. Psikomotor yeterlik, vücudun birden çok kısmının hedefe yönelik olarak hareketleri gönüllü olarak yerine getirmesidir (Gallahue \& Ozmun, 2006). Stanley (2009) bir işin yapılması esnasında kullanılan, bilinçli olarak yürütülen zihinsel etkinliklerin yönlendirmiş olduğu birbirleriyle uyumlu kas etkinliklerini psikomotor beceri olarak tanımlamıştır. Schmidt \& Wrisberg (2004) psikomotor becerinin bir işlemin üstesinden gelmek için kullanılan kas faaliyetleri şeklinde nitelendirmektedir. Örneğin, mikroskobun kullanılması küçük kas gelişimi gibi psikomotor becerileri ve teknik becerileri gerektirmektedir. Psikomotor beceriler ve teknik beceriler yuvarlama ve katlama gibi büyük kas gruplarının hareketlerine ve şekil verme ve detaylandırma işlemleri için de küçük kas gruplanının hareketlerine bağlı olarak şekillenmektedir (Kılıç, Haymana \& Bozyılmaz, 2008). Yani yapısal olarak yuvarlak bir şekle sahip olan hayvan hücresini meydana getirme sürecinde büyük kas gruplarının hareketlerinin yapısal olarak köşeli bir şekle sahip olan ve detaylandırmayı gerektiren bitki hücresini meydana getirme sürecinde küçük kas gruplarının hareketlerinin etkisi görülmektedir. Dolayısıyla da katılımcı grupların, hayvan hücresi modeline daha fazla vurgu yapmaları psikomotor yeterlik ve teknik beceri açısından kendilerini tanıdıkları ve bu beceriler açısından sınırlarını bildiklerini göstermektedir Bu bağlamda da katılımc1 gruplarında değindiği üzere hayvan hücresi modelini daha kolay meydana getirebileceklerini söylemek pekte yanlış olmayacaktır.

Modellerin sahip olması gereken özelliklere yönelik olarak katılımcı gruplar, modelin gerçeği yansıtması gerektiğini belirtmektedir. Grupların bu şekilde bir düşünceye sahip olmalarında araştırma kaynaklarından elde ettikleri verilerin etkisi bulunmaktadır. Gruplar, araştırma sürecinde birincil elden kendilerinin kullandıklanı ya da ikincil elden çevrelerinde bulunan bireylerin deneyimlerinden yararlanarak model konusunda bilgiye sahip olmaktadırlar. Bu durum, modellerin sahip olmaları gereken özellikler hususunda grupların araştırma kaynaklanından etkilendiklerini ve araştırma kaynaklarından elde edilen verilerin süreci ne denli etkilediğini gözler önüne sermektedir. Ancak literatürde model ve modellerin sahip olması gereken özelliklere yönelik olarak yürütülen çalışmalarda modellerin gerçeği yansıtma gibi bir özelliğinin olmasının gerekmediği, modellerin soyut, somut ya da karmaşık kavramların anlamlandırmak amacıyla kullanılması gerektiğine vurgu yapılmaktadır. Bu konuda Örnek (2008) tarafindan yürütülen çalışmada modellerin gerçeği tam anlamıyla yansıtmak zorunda olmadığı belirtilmiştir. Benzer şekilde Hestenes (2006), modellerin ilişkili olduğu objelerle arasında basitleştirilmiş bir ilişkinin olduğunu ve bire bir aynı özelliklerin olmasının anlamlı olmadığını ifade etmiştir. Van Driel \& Verloop (2002) ise bilimsel bir modelle hedef kavram arasında her zaman farkliliklar olabileceğini ifade ederek genel olarak ortaya çıkarılacak olan model olabildiğince basit yapıda ve yapılacak olan araştırmanın amaçlarına bağlı olarak hedefin bazı özelliklerini taşıyabilecek nitelikte olduğunu belirtmiştir. Bu bağlamda gruplann model konusunda eksik bilgileri ve kavramları içinde oldukları söylenebilir.

Modelleme konusunda etkinlikler meydana getirecek olan gruplar araştırma kapsamında kaynak olarak özellikle internetteki arama motoru olan Google Search'ü tercih ettiklerini ifade etmektedirler. Araştırmada böyle bir durumun ortaya çıkmasında bilim ve teknolojinin ilerleyişinin ve bu durumlara insanların ayak uydurma isteklerinin etkisi bulunmaktadır. Bilim ve teknoloji alanında meydana gelen değişimler bireylerin yaşantılarını önemli bir şekilde etkilemektedir (İnel, Evrekli \& Balım, 2011). Teknolojinin sürekli ve hızlı bir şekilde ilerlemesi bilimdeki gelişmeleri etkilemesinin yanı sıra bireylerin günlük hayat ihtiyaçlarına da doğru orantılı olarak yansımaktadır (Köseoğlu diğerleri, 2007). Bu bağlamda da insanlar bilgi ve iletişim teknolojilerini kullanmakta ve buna bağlı olarak da bilgi ve iletişim teknolojilerini kullanabilme yeterliliklerini geliştirmektedirler. Günümüzde çok küçük yaşlarda bulunan çocukların bile teknolojiyi kullanabilmeleri bu durum için etkili bir örnek olacaktır. Araştırma kapsamında da literatüre paralel bir sonucun çıkması bilgi ve iletişim teknolojilerinin hayatı ne kadar etkilediğini yeniden gözler önüne sermektedir. Fakat sadece herkese açı ve büyük bir bilgi kirliliği olan akademik anlamda çok fazla güvenilir bilginin yer almadı̆̆ arama 
motorlarından daha çok akademik ve bilimsel arama motorlarının üzerinden bu tür çalışmaları yapmaları öğrencilerin analitik düşünebilmeleri ve yaratıclıklarını arttırma konusunda daha faydalı olacaktır. Katılımcılar açısından düşünüldüğünde bu sürecin taklit etmeden öteye geçmediği görülmektedir.

Modelleme etkinliklerinde kullanmayı düşündükleri malzemeler hususunda tüm grupların oyun hamuru kullanıma vurgu yaptıkları karşımıza çıkmaktadır. Grupların bu şekilde bir düşünceye sahip olmalarında modelleme etkinliklerinde malzeme temini konusunda sorun yaşamamak istemeleri, malzemenin yapısal olarak esnek ve şekillendirilebilir olması ile bu malzemenin dikkat çekici olması nedeniyle tercih edildiği karşımıza çıkmaktadır. Konu ile ilgili olarak Sinan \& Karadeniz (2010) tarafından mitoz bölünme konusunun öğrencilere daha anlamlı bir şekilde öğretilmesi amacıyla yürütülen çalışmada, oyun hamurlarının süreç içerisinde etkin bir şekilde kullanıldığı ve hamurların sahip olmuş olduğu esneklik ve renk çeşitliliğinden dolayı eğitim - öğretim sürecinde tercih edilmesi gerektiğine vurgu yapılmaktadır. Bu duruma paralel olarak Metan (2008) ise, oyun hamurlarının birçok modelin yapılmasında kullanılabileceğini ve böylece öğrencilerin sürece aktif bir şekilde katılabileceğini ifade etmektedir. Oyun hamurları konusunda literatürde bulunan bu olumlu araştırmaların yanı sıra bu yapıların okulöncesi eğitimde öğrencilerin el kaslarının gelişimi için kullanıldığına da değinilmektedir. Dolayısıyla da çok küçük yaşlardan itibaren öğrenciler tarafindan kullanılan ve kabul edilen bir malzeme olduğu için ilerleyen yıllarda da tercih edilmesi oldukça doğaldır. Bu bağlamda araştırma sonuçlanı ile literatürün paralellik gösterdiği gözler önüne serilmektedir.

Modelleme etkinlikleri öncesinde G1, G2, G5 ve G6 kodlu gruplar araşturma kapsamında hayvan hücresi modelini yapacağını ifade etmekte ve süreç sonunda da bu modeli meydana getirmektedir. Gruplar ortak bir görüş olarak hayvan hücresi modelinde yer alan organellerin hedef yapı ile uyumlu olması gerektiğine vurgu yapmaktadırlar. Bu bağlamda da, G1 kodlu grubun hayvan hücresi modelinde sitoplâzma için jöleyi tercih etmiş olmaları organelin sahip olduğu akışkanlık özelliğini dikkate aldıklarını gözler önüne sermektedir. G2 kodlu grubun ise, malzeme temini noktasında sıkıntı yaşadıklarından bu amaçlarını tam olarak gerçekleştiremedikleri görülmektedir. G5 kodlu grup, modelde yer alan yapıların doğruluğuna dikkat çekmekte ve bu nedenle de oyun hamurlarının gerçeğe benzer şekilde hücre içerisinde yer alması gerektiğini belirtmektedir. Bu bağlamda da, farklı renklerde oyun hamurlarını kullanacaklarını ifade etmişler ve süreç içerisinde de modellerinde bu yapıları kullanmaktadırlar. G1 kodlu grup, zihinsel modellerinde malzemelerin ayırt ediciliğine dikkat çekmelerine rağmen sonuçta ortaya çıkardıkları modelde hücrenin temel yapıları dışında diğer organellere yer vermemekte bu durumda dikkat çekicilik unsurunu pek göze almadıklarını göstermektedir. G2 kodlu grubun ortaya çıkardıkları modellerde farklı ve canlı renkleri kullanmaları bu düşüncelerini gerçekleştirdiklerini gözler önüne sermektedir. G6 kodlu grup, modelde kabak, boncuk ve peçete kullanmaktadır. Kabak kullanmanın zorluğu ve peçetelerin ıslanması hususların dikkat çekilmekte ve bu tür malzemeler ile çalışmanın zorluğu ortaya çıkardıkları modelde de açıkça görülmektedir. Genel olarak grupların beklentileri ve sonuçları karşılaştırıldığı zaman, her iki durum arasında olumlu yönde bir korelasyonun olduğu söylenebilir. Sadece bir grubun malzeme temini konusunda sorun yaşayabilme ihtimalini göz önüne almadıklarını buna bağlı olarak ise beklenti ve sonuç arasında farklılıkların olduğu gözlenmektedir. Bu durumun da araştırma sürecinde incelenen katılımcıların esnek düşünebilme davranışı yönünden yeterli zihinsel olgunluğa erişemediklerini gözler önüne sermektedir. Ancak bu olumsuzluğun yanında grupların beklentileri ve sonuçları arasında kuvvetli derecede bir korelasyon bulunmaktadır. Bu durum ise katılımcıların beklentilere bağlı olarak modelleri meydana getirdiklerini gözler önüne sermektedir.

Modelleme etkinlikleri öncesinde G3 ve G4 kodlu gruplar araştırma kapsamında bitki hücresi modelini yapacağını ifade etmekte ve süreç sonunda da bu modeli meydana getirmektedir. G3 kodlu grup, zihinsel modelinde görüntü güzelliğinin önemini ve modelin dikkat çekici olması gerektiğini belirtmişlerdir. Ortaya koydukları model incelendiğinde de modelde farklı malzemelerin çeşitli amaçlar doğrultusunda kullanılmasının bu amaca hizmet ettiğini göstermektedir. G4 kodlu grup araştırma kapsamında farklı renklerde oyun hamurlarını kullanacaklarını söylemektedir. Nitekim oluşturdukları modelde de ifadelerinde yer aldığı üzere bu 
yapılara rastlanmaktadır. Fakat kullanmayı planladıkları ip çubuk gibi objelere modelde rastlanmamaktadır. Son olarak ise modelin renkleri ile ilgi çekici olması gerektiği ifade edilmekte ve bu bağlamda da modeldeki renkler de parlak ve ilgi çekici olduğu görülmektedir. Genel olarak grupların beklentileri ve sonuçları karşılaştırıldığı zaman, her iki durum arasında olumlu yönde bir korelasyonun olduğu söylenebilir. Grupların beklentileri ve sonuçları arasında bulunan zayıf korelasyonun ise grupların inisiyatifleri ve süreci olumlu bir şekilde tamamlayabilme düşünceleri ışığı altında şekillenmektedir. Bu bağlamda da katılımcıların beklentilerine bağlı olarak modellerini geliştirdiklerini söylemek pekte yanlış olmayacaktır.

\section{SONUÇ ve ÖNERİLER}

- Araştırmadan elde edilen bulgular doğrultusunda psikomotor yeterliklere bağlı olarak öğrenciler tarafından çeşitli tanımlamaların yapıldığı karşımıza çıkmaktadır. Öğrenciler sahip oldukları psikomotor yeterliklere bağı olarak model türünü seçmekte ve seçimini ifade etmektedir. Dolayısıyla da psikomotor yeterliklerin modelleme sürecinde oldukça önemli olduğu görülmektedir. Bu bağlamda da, öğrencilerin modelleme sürecinde sorun yaşamalarının önüne geçmek adına psikomotor yeterliklerini geliştirmeye yönelik egzersizler yapılmalıdır.

- Modelleme süreci içerisinde model oluşturacak olan öğrencilerin model konusunda çeşitli yanılgılara sahip oldukları karşımıza çıkmaktadır. Öğrencilerin bu şekilde bir yanılgıya sahip olmalarında deneyim açısından eksiklerinin olduğu düşünülmektedir. Bu bağlamda da öğrencilerin model konusu ile ilgili eksiklerinin giderilmesi için model ve modelleme konusunda öğrencilere eğitimler verilmeli ve öğrencilere basit düzeyde modelleme etkinlikleri yaptırllarak verilen eğitimler desteklenmelidir.

- Araştırma kapsamında öğrencilerin bilgi ve iletişim teknolojilerini etkin bir şekilde kullandıkları gözler önüne serilmektedir. Bu durumda 2013 yllında revize edilen Fen Bilimleri Dersi Öğretim Programı'nın uygulamaya konulduğunun ve araştıran-sorgulayan bireyler yetiştirildiğinin bir göstergesidir. Bu bağlamda da modelleme etkinlikleri, öğrencilerin araştıran-sorgulayan anlayışa göre yetişmelerini sağlaması ve öğretim programının hedeflerini dikkate alması doğrultusunda eğitim-öğretim sürecinde tercih edilmesi gereken araçlardan biri olmalıdır.

- Modelleme sürecinde malzeme seçimi konusunda öğrencilerin çoğunlukla oyun hamurunu tercih ettikleri görülmektedir. Öğrencilerin tercihlerini oyun hamurundan yana kullanmaları bu malzemenin esnekliğini, şekil verilebilirliğini ve dikkat çekicilik unsurunu göz önüne aldıklarını göstermektedir. Bu bağlamda da, modelleme sürecinde malzeme temini konusunda öğrencilerin sorun yaşamalarını önleme adına etkinliklerde oyun hamurunun tercih edilerek sürecin yürütülebileceği önerilebilir.

- Araştırmada, öğrencilerin sahip oldukları zihinsel modellerin, modelleme süreci sonrasında meydana getirdikleri modellere yansıdıkları karşımıza çıkmaktadır. Bu durum, zihinsel modellerin modelleme süreci için oldukça önemli olduğunu gözler önüne sermektedir. Ayrıca, araştırmada öğrencilerin sahip oldukları zihinsel modeller ile meydana getirdikleri modellerin karşılaştırmasının yapılması bu çalışmanın önemini bir kez daha göstermektedir. Bu bağlamda da, öğrencilerin sahip oldukları zihinsel modellerin derinlemesine incelenmesinin sağlanması ve zihinsel modellerin meydana getirilme sürecine yönelik olarak çeşitli çalışmaların yapılması önerilmektedir.

\section{KAYNAKÇA}

Altuntaş Aydın, M. (2011). Model ve kavramsal değișim metinlerinin birlikte kullanulmasinn ilkögretim 7.smnf ögrencilerinin atomun yapısı konusunu anlamalar ü̈zerine etkisi. (Yayımlanmamış yüksek lisans tezi). Karadeniz Teknik Üniversitesi, Trabzon.

Arslan, A. (2013). Modellemeye dayah fen ögretiminin ilk:ögretim ögrencilerinin anlama, hatırda tutma, yaratıchlk düzeyleri ile ziłhinsel modelleri üzerine etkisi. (Yayımlanmamış yüksek lisans tezi). Akdeniz Üniversitesi, Antalya.

Aydın, G. (2011). Öğrencilerin bü̈re bölünmesi ve kahtım konularndaki kavram yanılgılarnnn giderilmesine ve zibinsel modelleri üzerine yapılandermacı yaklaşımın etkisi. (Yayımlanmamış doktora tezi). Dokuz Eylül Üniversitesi, İzmir. 
Ayvacı, H. Ş. \& Çoruhlu, T. Ş. (2012). Fen ve teknoloji öğretmen adaylarının bilim ve fen kavramlanı ile ilgili sahip oldukları görüşlerin araştırılması. Dicle Üniversitesi Zìa Gökalp Ë̆itim Fakültesi Dergisi, 19, 29-37.

Başkan, Z. (2011). Doğrusal ve düzlemde hareket ünitelerinin matematiksel modelleme kullanlarak ögretiminin ögretmen adaylarmın ögrenmelerine etkileri. (Yayımlanmamış doktora tezi). Karadeniz Teknik Üniversitesi, Trabzon.

Batı, K. (2014). Modellemeye dayal fen eğitiminin etkililiüg; Bu eğitimin ögrencilerin bilimin doğast görüsleri ile eleștirel dïşünme becerilerine etkisi. (Yayımlanmamış doktora tezi). Hacettepe Üniversitesi, Ankara.

Bilgin, İ. \& Geban, Ö. (2001). Benzeşim yöntemi kullanılarak lise 2.sınıf öğrencilerinin kimyasal denge konusundaki kavram yanılgilarının giderilmesi. Hacettepe Üniversitesi Eğitim Fakëiltesi Dergisi, 20, 26-32.

Büyüköztürk, S., Kılıç Çakmak, E., Akgün, O. E., Karadeniz, S. \& Demirel, F. (2011). Bilimsel Araștırma Yöntemleri (8.Baski), Ankara: PEGEM Akademi.

Cohen, L., Manion, L. \& Morrison, K. (2000). Research methods in education (5th ed.). New York: Routledge Falmer.

Coll, R. K. \& Treagust, D. F. (2003). Learners' mental models of metalic bonding: A cross-age study. Science Education, 87, 685-707.

Creswell, J. (2003). Research design: Qualitative, quantitative and mixed methods approaches (2nd ed.). Thousand Oaks, CA: SAGE Publications.

Çepni, S. (2010). Araştırma ve Proje Çalısmalarnna Giriș (5.Baske), Trabzon: Ofset Matbaacıllk.

Esendemir, G. (2014). Effect of physical modeling and computer animation implemented with social constructivist instruction on understanding of human reproductive system. (Yayımlanmamış doktora tezi). ODTÜ, Ankara.

Gallahue, D. \& Ozmun, J. C. (2006). Understanding Motor Development, Infants, Childrens, Adolescents and Adults (6th Edition), New York: McGraw-Hill Companies.

Gümüş, İ., Demir, Y., Koçak, E., Kaya, Y. \& Kıncı, M. (2008). Modelle öğretimin öğrenci başarısına etkisi. Eræincan Ë̆itim Fakültesi Dergisi, 10(1), 65-90.

Gobert, J. D. \& Buckley, B. C. (2000). Introduction to model-based teaching and learning. International Journal of Science Education, 22(9), 891-894.

Harrison, A. G. (2001). How do teachers and textbook writers model scientific ideas for students?. Research in Science Education, 31, 401-435.

Harrison, A. G. \& Treagust, D. F. (2000). A typology of school science models. International Journal of Science Education, 22(9), 1011-1026.

Hestenes, D. (2006). Notes for a modeling theory of science, cognition and instruction. proceedings of the 2006 GIREP Conference. Modelling in Physics and Physics Education. (20-25 August 2006). Amsterdam.

İnel, D., Evrekli, E. \& Balım, A. G. (2011). Öğretmen adaylarının fen ve teknoloji dersinde eğitim teknolojilerinin kullanılmasına ilişkin görüşleri. Kuramsal Ë̆̈itimbilim Dergisi, 4(2), 128 - 150.

İyibil, Ü. \& Sağlam Arslan, A. (2010). Fizik öğretmen adaylarının yıldız kavramına dair zihinsel modelleri. Necatibey Eğitim Fakültesi Elektronik Fen ve Matematik Eğitimi Dergisi (EFMED), 4(2), 25-46.

Justi, R. S. \& Gilbert, J. K. (2002) Modelling, teachers' views on the nature of modelling, and implications for the education of modellers. International Journal of Science Education, 24(4), 369-387.

Kaptan, S. \& Aslan, B. (2002). Fen öğretiminde soru-cevap tekniği ile analoji tekniğinin karşılașturlması. $V$. Ulusal Fen Bilimleri ve Matematik Eğitimi Kongresi, Poster Bildiri, 16-18 Eylül 2002,ODTÜ, Ankara.

Kılıç, G.B., Haymana, F. \& Bozyılmaz, B. (2008). İlköğretim fen ve teknoloji dersi öğretim programının bilim okuryazarllğ1 ve bilimsel süreç becerileri açısından analizi. Ĕ̈itim ve Bilim Dergisi, 33(150), 52-63.

Koçak, E. (2006). Illkögrretim 5. simf ögrencilerinde "Sindirim ve Görevli Yapılar", "Boșaltım ve Görevli Yapılar" ve "Ciçekli Bir Bitkiyi Tanyalım" konularmm modelle ögretiminin öğrenci başarssina etkisi. (Yayımlanmamış yüksek lisans tezi). Atatürk Üniversitesi, Erzurum.

Köseoğlu, P., Yılmaz, M., Gerçek, C. \& Soran, H. (2007). Bilgisayar kursunun bilgisayara yönelik basarı, tutum ve öz yeterlik inançlan üzerine etkisi. Hacettepe Üniversitesi Ĕ̈itim Fakülttesi Dergisi, 33, 203 - 209.

Kurnaz, M. A. \& Değermenci, A. (2012). 7.sınıf öğrencilerinin güneş, dünya ve ay ile ilgili zihinsel modelleri. İlkögretim Online, 11(1), 137-150.

Küçüközer, H. (2008). The effects of 3d computer modelling on conceptual change about seasons and phases of the moon. Physics Education, 43(6), 632-636.

Méheut, M. (2004). Designing and validating two teaching-learning sequences about particle models. International Journal of Science Education, 26(5), 605-618.

Metan, E. (2008). Cocuk kitabı resimlemesinde oyun hamuru (plastilin) kullanım ve bir uygulama. (Yayımlanmamıș yüksek lisans tezi). Hacettepe Üniversitesi, Ankara. 
Minaslı, E. (2009). Fen ve teknoloji dersi maddenin yapısı ve özellikleri ünitesinin ögretilmesinde simülasyon ve model kullanılmasinın bașaryya, kavram ögrenmeye ve hatorlamaya etkisi. (Yayımlanmamış yüksek lisans tezi). Marmara Üniversitesi, İstanbul.

Nakiboğlu, C., Karakoç, Ö. \& Benlikaya, R. (2002). Kimya öğretmen adaylarının atomun yapısı ile ilgili zihinsel modelleri. XVI. Ulusal Kimya Kongresi, 10-13 Eylül, Selçuk Üniversitesi, Konya.

Ogan-Bekiroğlu, F. (2007). Effects of model-based teaching on pre-service physics teachers' conceptions of the moon, moon phases, and other lunar phenomena. International Journal of Science Education, 29(5), 555-593.

Örnek, F. (2008). Models in Science education: applications of models in learning and teaching science. International Journal of Environmental \& Science Education, 3(2), 35 - 45.

Sinan, O. \& Karadeniz, Ö. (2010). Mitoz bölünme konusunun öğretimi için örnek bir etkinlik. İlkögrretim Online Dergisi, 9(3), 1-7.

Schmidt RA. \& Wrisberg CA. (2004). Motor Learning and Performance (3rd Edition), Champaign IL: Human Kinetics.

Stanley, M. (2009). Çocuk ve Beceri (Editör: İlayda Özbaş), İstanbul: Ekinoks Yayıncilık.

Şencan, H. (2005). Sosyal ve Davramsssal Ölçümlerde Güvenilirlik ve Geģerlilik, Ankara: Seçkin Yayıncılık.

Ünal, G. (2005). Fen ögretiminde derinlĭ̆g ögrenme: Basınç konusunda modelleme. (Yayımlanmamış yüksek lisans tezi). Dokuz Eylül Üniversitesi, İzmir.

Ünal, G. \& Ergin, Ö. (2006). Fen eğitimi ve modeller. Milli Eğitim Dergisi, 171, 188-196.

Ünal Çoban, G. (2009). Modellemeye dayah fen ögretiminin ögrencilerin kavramsal anlama düzeylerine, bilimsel sürec becerilerine, bilimsel bilgi ve varlık anlayışlarna etkisi: 7. Simf ışık ünitesi örneği. (Yayımlanmamış doktora tezi). Dokuz Eylül Üniversitesi, İzmir.

Van Driel, J. H. \& Verloop, N. (2002). Experienced teachers' knowledge of teaching and learning of models and modelling in science education. International Journal of Science Education, 24(12), 1255-1272.

Woolridge, D. K. (2000). Formal modeling in an introductory college physics course. (Unpublished master thesis). Faculty of Education Memorial University of Newfounland.

Yıldırım, A. \& Şimşek, H. (2008). Sosyal bilimlerde Nitel Araştırma Yöntemleri (7. Baskı), Ankara: Seçkin Yayıncillk.

Yıldız, H. T. (2006). İlkögretim ve ortä̈ğretim ögrrencilerinin atomun yapısı ile ilgili zibinsel modelleri. (Yayımlanmamış yüksek lisans tezi). Balıkesir Üniversitesi, Balıkesir.

\section{Citation Information}

Ayvacı, H., Ş., Bebek, G., Atik, A., Keleş, C., B. \& Özdemir, N. (2016) Öğrencilerin Sahip Oldukları Zihinsel Modellerin Modelleme Süreci İçerisinde İncelenmesi: Hücre Konusu Örneği. Dicle Üniversitesi Ziya Gökalp Eğitim Fakültesi Dergisi, 28, 175-188. 